\title{
EDITORIAL
}

\section{THE DISAPPEARED AND THEIR FAMILIES: WHEN SUFFERING IS MIXED WITH HOPE}

\section{Vincent Bernard, Editor-in-Chief}

Every day, people go missing amidst conflict and violence, or on the paths of exile, displacement or migration. Meanwhile, those whose loved ones went missing in the past continue to live with their pain, unable to heal. Long after the wars or disasters are over, the wounded have been cared for and the new have been homes built upon the ruins of the old ones, the suffering of people whose loved ones are missing lingers on, the last open wound.

Where is my child? Is he a prisoner? Did she suffer when they killed her? Will she ever come back? Where are they buried? For those in the dark about what happened to a loved one, the hope that they will return, a sign of life or even a scrap of information can become an obsession-suffering that is both acute and haunting.

If answers never come, loved ones will carry the burden of their questions and grief throughout their lives and to their graves, often consoled only by the unshakeable faith that they will then be reunited with their son, daughter, parent or spouse.

Pauline Boss uses the term "ambiguous loss" to describe the unique suffering of living in uncertainty about the fate of a loved one. In the words of one of the families of missing migrants in Zimbabwe published in the Review's recent issue on migration and displacement: "The greatest source of pain is not knowing whether he is alive or not."

The psychological trauma is compounded by a series of pressing, multifaceted needs when it is the breadwinner who goes missing. Not only can the family find themselves unable to make ends meet, they are in legal limbo, unable to exercise their rights to inherit or sell property or even carry out basic administrative formalities. ${ }^{3}$

The suffering of those who do not know what happened to their loved ones remains one of the least visible humanitarian problems. Worse, these families' needs are often ignored, exploited or even swept under the rug for political ends: whether the fate of the missing will be resolved is determined by those acting in the name of the "greater good" for reconciliation, or its opposite, becoming a pretext to fuel a climate of fear and revenge. Cases of missing persons may be denied to cover up a crime; they may also trigger, become the crux of, or perpetuate a conflict. For example, the disappearance of two Israeli soldiers on the border between Israel and Lebanon sparked the 2006 war, and the identification of their remains was a necessary precondition to the resolution of that conflict. ${ }^{4}$ 
Anthropologists consider that the appearance of funeral rites marks the transition to civilization for human communities. Although much of the focus in humanitarian action is put on the families who are searching for their loved ones, identifying human remains not only brings answers to families but also ensures that the humanity of the deceased is respected. As Morris Tidball-Binz, pioneer in humanitarian forensics, says in his interview for this issue of the Review, "by helping fulfil the obligations towards the dead, we reassert our own humanity". 5

Whether wounded, shipwrecked, detained in secret or unable to communicate for any number of other reasons, not all missing persons are dead, and their families, waiting for news, will continue to hope that their loved ones are among the living until they know for sure. Just as Penelope waited for Odysseus in The Odyssey - and others have done throughout history - those with missing loved ones are trapped in a state of eternal waiting and searching.

For centuries, the tragic fate of the missing and their families was considered inevitable. The remains of the victims of wars or disasters were rarely identified and returned to their families, whether out of vengeance, indifference or simply lack of means to do so.

Since the nineteenth century and the development of international humanitarian action, humanitarian organizations have been continually coming up with new solutions. In recent years, greater awareness of the scale of the problem, thanks to the efforts of the families, coupled with advances in forensic science, genetics, facial recognition, and means of communication and transport, have led to great strides forward. These advances could prevent people going missing in the first place or bring answers for the families of the missing.

In many contexts, however, the political will to devote the necessary means to prevent people from going missing, search for the missing and identify remains to help find answers is still lacking. And even when the political will is there, authorities too often do not know what measures to take to collect and share information about missing persons. Similarly, the authorities may not know how to address the families' precarious circumstances and legal and administrative limbo.

In this issue on missing persons, ${ }^{6}$ the Review takes stock of recent advances in the humanitarian sector with the aim of promoting best practices and mobilizing

1 See Pauline Boss, "Families of the Missing: Psychosocial Effects and Therapeutic Approaches", in this issue of the Review.

2 “'All I Want Is to Know': Testimonies of the Families of Missing Migrants in Zimbabwe”, International Review of the Red Cross, Vol. 99, No. 904, 2018, p. 15.

3 On the needs of families, see, in particular, ICRC, Accompanying the Families of Missing Persons: A Practical Handbook, Geneva, 2013, available at: https://shop.icrc.org/accompagner-les-familles-despersonnes-portees-disparues-2383.html (all internet references were accessed in July 2018).

4 For more on this and other examples of how forensic work contributes to humanitarian action, see the "Using forensic science to care for the dead and search for the missing: In conversation with Morris Tidball-Binz" in this issue of the Review.

5 See also Oran Finegan, "Dignity in Death: Remembrance and the Voice of the Dead", Humanitarian Law and Policy blog, ICRC, 1 November 2017, available at: http://blogs.icrc.org/law-and-policy/2017/11/01/ dignity-in-death-remembrance-and-the-voice-of-the-dead.

6 The Review has previously run a themed issue on missing persons (Vol. 84, No. 848, 2002). 
action to clarify the fate and whereabouts of missing persons and respond to the needs of their families.

\section{The missing in contemporary history}

On the battlefields of North America and Europe, it was only in the nineteenth century, with the dawn of modern humanitarianism, that the response started to become organized. At the end of the American Civil War, the War Department - which had kept no record of the dead or the wounded during the war - struggled to cope with prisoner repatriation. Clara Barton, founder of the American Red Cross, published an appeal to "The friends of missing persons":

Miss Clara Barton has kindly offered to search for the missing prisoners-of-war. Please address her at Annapolis, giving name, regiment, and company of any missing prisoner. ${ }^{7}$

Provided with a table and a tent by the army, she proceeded to set up a service to track down missing soldiers who had been prisoners of war. Around the same time, in addition to providing medical and material relief, Henry Dunant also wrote to the families of those dying after the Battle of Solferino, telling them of the fate of their loved ones. But the remains of thousands of soldiers were buried haphazardly during the Italian campaign and finally piled together in ossuaries, with no possibility of identifying them.

A few years later, when the Franco-Prussian War of 1870 broke out, the International Committee for Relief to the Wounded set up the Information Bureau of the International Relief Agency for Wounded and Sick Soldiers. This organization was the forerunner of today's Central Tracing Agency, ${ }^{8}$ a permanent structure within the International Committee of the Red Cross (ICRC) that is tasked with finding out what happened to missing, wounded and captured soldiers, informing their families, and putting them in contact wherever possible. ${ }^{9}$

The twentieth century was the century of people unaccounted for on a massive scale: the mass slaughter of industrial warfare and the genocides and massacres of civilians resulted in millions of people unaccounted for. On the battlefields of the First World War, the artillery churned up the earth, destroyed bodies, and buried soldiers alive or dead in their trenches. A British lieutenant wrote these lines in his journal on 1 July 1916, the first day of the Battle of the Somme:

7 Quoted in Caroline Moorehead, Dunant's Dream: War, Switzerland and the History of the Red Cross, Caroll \& Graf, New York, 1999, p. 89.

8 ICRC, "History of the Central Tracing Agency of the ICRC", 2002, available at: www.icrc.org/eng/ resources/documents/misc/57jqri.htm

9 More information about the Restoring Family Links network and the role of the Central Tracing Agency is available at: https://familylinks.icrc.org/en/pages/home.aspx. 
I am back in Maricourt writing this: after writing my last we endured perfect hell for a couple of hours, shells landing within a few feet of us every seconds. Then three men came across from the opposite dugout to say it had been blown in and ten men lying buried in it. Not the slightest use trying to dig them out. It would be a day or more's job and they're already dead. ${ }^{10}$

Those ten men may still be there, somewhere in a field near Maricourt. The soldiers, dragged from civilian life, from their families, may have feared being forgotten more than death. In going to the front they knew that there was not only the risk of injury or death, but also the prospect of simply disappearing, engulfed by a storm of metal and fire.

In an effort to conjure that fear, Constantin Simonov wrote "Wait for Me" in 1941, one of the best-known Russian poems of the Second World War. Here is an excerpt:

Wait when yesterdays are past,

Others are forgot.

Wait, when from that far-off place,

Letters don't arrive.

Wait, when those with whom you wait

Doubt if I'm alive.

Wait for me, and I'll come back!

Wait in patience yet

When they tell you off by heart

That you should forget. ${ }^{11}$

After the two World Wars, monuments, graves of unknown soldiers and ossuaries sprang up in many places. These sites allowed States to commemorate their dead and, incidentally, were also places where families could come to mourn when they had no individual grave to visit. Even today, mechanical diggers and farmers' tractors continue to unearth the remains of soldiers from the two World Wars along the areas where the front lines used to be. Some are still wearing their identification tags, which became widely used by armies at the beginning of the twentieth century. ${ }^{12}$ It is those tags that make it possible to identify them and inform their families, even a century later. According to international humanitarian law (IHL), the task of collecting and identifying the soldiers' remains, informing their families and keeping their memory alive falls to the belligerents. But not all soldiers are equal in death, and some countries invest much more in remembering the fallen than others.

10 Lieutenant Russell-Jones, quoted in Anthony Richards, The Somme: A Visual History, Imperial War Museums, London, 2016, p. 89.

11 Translated from Russian, available at: www.simonov.co.uk/waitforme.htm.

12 The US Army first ordered the use of identification tags in War Department General Order No. 204 of 20 December 1906. 
Mindsets are changing: in societies that have entered a "post-heroic" era, public opinion no longer finds military losses acceptable, and the death of soldiers is no longer seen as a necessary, glorious sacrifice. In contrast to the mass slaughter of the World Wars, some countries now take great care to ensure that their soldiers are not lost and to repatriate their remains when they die in combat. "Leave no man behind" has become the US military credo, popularized by cinema (e.g. Black Hawk Down) and equally applicable to both the living and the dead.

Victims of ideological, racial or religious repression have had their humanity denied even in death, leaving a daunting and perhaps insurmountable obstacle to restoring their identities and therefore their dignity after death. For example, the Nazis burnt and scattered the ashes of millions of Jews and other victims of their fanaticism in factories of death. The perpetrators of the Rwandan genocide did not bother to bury their victims' bodies: the Rwandan Patriotic Front fighters who put an end to three months of genocide against the Tutsi found their remains left in the open across the country. Even today, the families of victims of these genocides search for answers. ${ }^{13}$

Not only those killed but also those detained are at risk of losing contact with their families. The number of prisoners of war shot up during the two World Wars. To keep them in touch with their families when the traditional communication channels between the belligerents were cut, the efforts of the ICRC as a neutral humanitarian intermediary intensified and proved their worth. Some of the millions of individual index cards, written by hand by ICRC staff during wartime to identify and specify the location of the prisoners and inform their families of their fate, are on display today at the International Red Cross and Red Crescent Museum in Geneva. These archives were included in the UNESCO Memory of the World Register in 2007.

The sheer number of cases of those missing or at risk of going missing can be daunting, but technology has always been harnessed for this humanitarian cause. In 1939 the firm IBM supplied the ICRC with punchcard machines - the first example of modern technology put to the service of tracing efforts. ${ }^{14}$ These new punchcards were an improvement upon the system used during the First World War, and thanks to these machines, the ICRC was able to process the records of 50,300 French soldiers who went missing during the 1940 campaign. ${ }^{15}$

Since then, the tracing service has continually modernized and its expertise continues to be sought when mass tragedies occur. As a testament to those tragedies and the immense humanitarian work carried out in their wake, the International

13 See website of the International Tracing Service, an organization dedicated to tracing and documenting people who went missing during the Shoah, available at: www.its-arolsen.org/en/; Erin Jessee, "Promoting reconciliation through identifying victims of the 1994 Rwandan genocide", Centre for International Governance Innovation, Africa Initiative Discussion Paper Series, Vol. 4, 2012, available at: https://strathprints.strath.ac.uk/48264/1/CIGI_AI_Discussion_Paper_4_Erin_Jessee.pdf.

14 Monique Katz, "Quand des machines travaillaient pour la Croix-Rouge", International Review of the Red Cross, Vol. 38, No. 453, 1956.

15 L'activité du Service Watson, 21 June 1946, ICRC Archives, C G2 WA 1994.042.0001, Service Watson, 1939-1945. 
Red Cross and Red Crescent Museum in Geneva also has on display some of the thousands of photos of children who became separated from their families during the Rwandan genocide and subsequent conflicts in the region, as well as an exhibit dedicated to those who went missing during the conflict in the former Yugoslavia.

Families are not passive in their suffering, but play an active role in the search for their loved ones. For example, mothers and grandmothers whose loved ones went missing under the military dictatorship in Argentina from 1976 to 1983 raised awareness by protesting in the Plaza de Mayo in Buenos Aires to demand answers about what happened to their missing relatives. Their tireless efforts served as a catalyst for the development of humanitarian forensics, bringing about important advances in genetic testing, data collection and public campaigning. Genetic testing also made it possible to trace many children born in captivity and placed with other families after their parents were killed.

The struggle of the Plaza de Mayo mothers and grandmothers continues to this day. In this edition, the Review was privileged to interview Estela Barnes de Carlotto, president of the Grandmothers of the Plaza de Mayo association and one of the truly inspirational figures of our time. Having lost her daughter, who was killed in 1977, she discovered that she had a grandson who had been born in captivity and taken away. Decades later, the genetic data bank and the information campaigns that she herself had helped to set up in Argentina made it possible to find him, and they were reunited.

Today, people in places affected by conflict and other situations of violence continue to endure similar ordeals. This issue of the Review deals in particular with cases of disappearance during the conflict in Sri Lanka ${ }^{16}$ and victims of criminal violence in Latin America. ${ }^{17}$ But thousands also go missing among displaced people and migrants along their journey, and their fate concerns the countries of origin, transit and destination. The phenomenon of disappearance has therefore become both chronic in light of today's protracted conflicts and global in the context of displacement and migration.

\section{International law and humanitarian policy}

The ICRC defines missing persons as those whose whereabouts are unknown to their relatives and/or who, on the basis of reliable information, have been reported missing in connection with an international or non-international armed conflict, other situation of violence, natural disaster or any other situation that

16 See Maleeka Salih and Gameela Samarasinghe, "Families of the Missing in Sri Lanka: Psychosocial Considerations in Transitional Justice Mechanisms"; Isabelle Lassée, "The Sri Lankan Office on Missing Persons: Truth and Justice in Tandem?"; and Vishakha Wijenayake, "The Office on Missing Persons in Sri Lanka: The Importance of a Primarily Humanitarian Mandate", in this issue of the Review.

17 See Gabriella Citroni, "The First Attempts in Mexico and Central America to Address the Phenomenon of Missing and Disappeared Migrants", in this issue of the Review. 
might require action by a neutral and independent body, including in the context of migration. ${ }^{18}$

Governments, military authorities and armed groups have a duty to prevent disappearances. They also have a duty to provide information and participate in efforts to reunite families.

IHL stipulates that the right of families to know what happened to their loved ones who went missing in armed conflict must be upheld and safeguarded. They have the right to be reunited with them if they are still alive. If they are dead, the families have the right to mourn them with dignity and in accordance with their beliefs and traditions. Like many of the rules embodied in IHL, this is in line with the many older ethical, moral and religious norms. For example, Islamic law has similar provisions, and may even be more protective under certain circumstances. ${ }^{19}$

Experience has shown that in the event of legal proceedings against those accused of enforced disappearance, the authorities must also seek to clarify the fate of the missing and work in a complementary way with humanitarian organizations. The families of the missing and their specific needs must be recognized by the authorities, and must be involved in developing the policies that will concern them. The ICRC works diligently to ensure that the issue of missing persons is put on the agenda of transitional justice processes, and insists that the needs of victims and their families are taken seriously.

There has long been a false dichotomy drawn between families' right to know and criminal accountability for any crimes that led to the disappearance of their loved ones. However, clarifying the fate and whereabouts of missing persons is, in fact, a complementary objective to the pursuit of justice. ${ }^{20}$

International rules on handling human remains in the context of armed conflict and cases of enforced disappearance are set out in the 1949 Geneva Conventions and the International Convention for the Protection of All Persons from Enforced Disappearance, ${ }^{21}$ which was adopted in 2007 and came into force in 2010. The obligation to return the remains of missing and forcibly disappeared persons to their families has gained acceptance and has been progressively developed over time by the international community, both at the international and domestic levels. ${ }^{22}$

18 ICRC, The Domestic Implementation of International Humanitarian Law: A Manual, Geneva, 2015, available at: https://shop.icrc.org/la-mise-en-oeuvre-du-droit-humanitaire-manuel-version-cederom-2482. html.

19 See Ahmed Al-Dawoody, "Management of the Dead from the Islamic law and International Humanitarian Law Perspectives: Considerations for Humanitarian Forensics", in this issue of the Review.

20 To read two perspectives on how a particular mechanism deals with the relationship between truth and justice, see the articles by Vishakha Wijenayake and Isabelle Lassée in this issue of the Review. To read about missing mechanisms more generally, see Monique Crettol, Lina Milner, Anne-Marie La Rosa and Jill Stockwell, "Establishing Mechanisms to Clarify the Fate and Whereabouts of Missing Persons: A Proposed Humanitarian Approach", also in this issue of the Review.

21 See: www.ohchr.org/EN/ProfessionalInterest/Pages/IntConventionEnforcedDisappearance.aspx.

22 See Grazyna Baranowska, "Advances and Progress in the Obligation to Return the Remains of Missing and Forcibly Disappeared Persons", in this issue of the Review. 
In 2017, the UN Working Group on Enforced or Involuntary Disappearances (WGEID), a Special Procedure of the Human Rights Council, submitted a report on enforced disappearances in the context of migration, signalling that the phenomenon of missing migrants had reached a scale that required a humanitarian response at the international level. ${ }^{23}$ Cases of missing migrants require transnational, even global action involving many parties. It can seem an impossible task given the complexity of individual and mass migrations and the sheer number of routes taken by migrants, but there are nevertheless concrete measures that can be taken to prevent people from going missing, keep them in contact with their families, identify mortal remains and inform the families. For instance, helping migrants and their families stay in touch during their journey and once they arrive at their destination, if they wish, including in detention centres; standardizing the collection of data from migrants' families in their places of origin and protecting that data for use for humanitarian purposes only; and setting up national databases to standardize and centralize information on unidentified remains.

\section{The humanitarian work of the International Red Cross and Red Crescent Movement}

The ICRC and its partners in the International Red Cross and Red Crescent Movement (the Movement) have developed a multidisciplinary approach to addressing humanitarian problems, including missing persons. This begins with prevention - for example, a series of training and awareness-raising measures, such as comic books and animated films on the issue of missing persons as a significant humanitarian challenge. ${ }^{24}$

The Movement has put in place a worldwide Restoring Family Links network, made up of National Red Cross and Red Crescent Societies (National Societies) and ICRC delegations, managed and coordinated by the Central Tracing Agency. ${ }^{25}$ While for decades handwritten Red Cross messages on simple paper forms were the main way to exchange news between separated family members, in the era of social media and smart phones there is still a need for the

23 WGEID, Report of the Working Group on Enforced or Involuntary Disappearances on Enforced Disappearances in theContext of Migration, UN Doc. A/HRC/36/39/Add.2, 28 July 2017. See also Bernard Duhaime and Andréanne Thibault, "Protection of Migrants from Enforced Disappearance: A Human Rights Perspective", in this issue of the Review.

24 See, for example, ICRC, "Drawn Together: The Plight of the Missing", 30 August 2016, available at: www. icrc.org/en/document/drawn-together-plight-missing. To mark the International Day of the Disappeared on 30 August 2017, the ICRC's Central Tracing Agency and Protection Division and the Review organized a panel discussion entitled "Gone but not Forgotten" at the ICRC's Humanitarium conference centre, available at: www.icrc.org/en/document/gone-not-forgotten-migrants-mothers-and-missing.

25 See also the Restoring Family Links Strategy of the International Red Cross and Red Crescent Movement, approved at the 30th International Conference of the Red Cross and Red Crescent in 2007, available at: https://shop.icrc.org/strategie-de-retablissement-des-liens-familiaux-y-compris-references-juridiques2639.html. 
Agency's services. In fact, there are many people who do not have access to these technologies or are unable to use them, for example when they have been detained.

With its long experience in restoring family links, the ICRC began developing activities to support the families of missing persons in $1991 .^{26}$ The ICRC now works with such families in twenty countries, including Colombia, Lebanon, Mexico, Senegal, Sri Lanka and Ukraine.

The ICRC also supports States' efforts to ascertain the fate of missing persons through various means. This may take the form of assisting the establishment of coordination mechanisms between the former parties to a conflict or national mechanisms on missing persons, and providing technical advice, once these become active (e.g. in Colombia, Peru and Sri Lanka). The ICRC also participates in coordination mechanisms, sometimes chairing such mechanisms (e.g. the coordination mechanism concerning Georgia/Abkhazia/ South Ossetia; the Tripartate Commission between Iraq, Kuwait and the 19901991 coalition; and the Kosovo Working Group on Missing Persons). Finally, the ICRC's Advisory Service on IHL provides legal and technical support to States seeking to enact legislation to implement their international obligations regarding missing persons and their families. To this end, it has come up with guiding principles and model laws, ${ }^{27}$ as well as facilitating the sharing of laws and case law between States. ${ }^{28}$

In the early 2000s the ICRC began developing expertise in forensic science - uniquely, for humanitarian purposes, rather than for scientific, medical or legal purposes. When people die during war, disaster or migration, their remains must be handled with respect and dignity, and unidentified remains must be searched for, recovered and identified. Humanitarian forensics - derived from techniques originally developed to identify remains and determine the cause of death as part of criminal proceedings - offer new possibilities for achieving these aims. ${ }^{29}$ Generally speaking, the ICRC helps to build local capacity (e.g. in South Africa, Mexico, the Philippines and Yemen), ${ }^{30}$ but it also carries out exhumation and identification operations directly, in its capacity as an independent, neutral humanitarian organization. Argentina and the United Kingdom recently called upon the ICRC to identify the remains of soldiers killed

ICRC, above note 3 .

27 See: www.icrc.org/eng/resources/documents/misc/missing-model-law-010907.htm.

28 See: https://ihl-databases.icrc.org/ihl-nat.

29 See, in particular: www.icrc.org/en/what-we-do/forensic-science; ICRC, Missing People: DNA Analysis and Identification of Human Remains: A Guide to Best Practice in Armed Conflicts and Other Situations of Violence, Geneva, 2009, available at: https://tinyurl.com/yarmwuao.

30 ICRC, "South Africa: Using Forensics to Uncover the Fate of the Missing", 1 September 2016, available at: www.icrc.org/en/document/south-africa-finding-answers-about-fate-missing; ICRC, "Forensic Science and Humanitarian Action", 1 January 2017, available at: www.icrc.org/en/document/forensic-scienceand-humanitarian-action; ICRC, "Philippines: Helping Identify the Dead", 19 November 2013, available at: www.icrc.org/eng/resources/documents/news-release/2013/11-19-philippines-dead-bodiesmanagement.htm; Alex Emmons, "The Death Toll in Yemen is So High the Red Cross Has Started Donating Morgues to Hospitals", The Intercept, 25 August 2016, available at: https://theintercept.com/ 2016/08/25/the-death-toll-in-yemen-is-so-high-the-red-cross-has-started-donating-morgues-tohospitals/. 
during the war in the Falkland/Malvinas Islands, thirty-five years after the fighting ended. In this issue of the Review, Morris Tidball-Binz recounts this humanitarian operation and reflects on the development of this new area of work for the ICRC.

In 2002 the ICRC conducted an assessment of its activities for missing persons and their families, which resulted in new impetus being given to this area of work at the 28th International Conference of the Red Cross and Red Crescent in $2003 .{ }^{31}$

In relation to missing migrants, the ICRC has produced a series of recommendations for policy-makers based on its field experience. ${ }^{32}$ To help efforts to identify the human remains found along the migration routes of West Africa, the ICRC has set up a regional pilot project in collaboration with the National Societies of Mali, Mauritania and Senegal. The Trace the Face service was set up in 2016 in the hope of reconnecting relatives who had become separated. National Societies publish photos of people looking for their missing relatives, online and on posters. ${ }^{33}$ Facial recognition programmes are now being used to identify people's remains. As we have seen throughout history, this field is far from static, and humanitarians have always made use of the latest technology. ${ }^{34}$

The issue of missing persons requires a holistic response. Following a stocktaking exercise of missing-related activities in twenty-two of its operational delegations, in 2018 the ICRC launched a new Missing Persons Project aimed at developing international standards in this field. ${ }^{35}$ By organizing a series of meetings of stakeholders in the coming years, the ICRC hopes to foster the development of standards on (1) collecting and protecting data on people most at risk of going missing, (2) dead body management and identification, (3) mechanisms to ascertain the fate of missing persons, (4) harnessing big data and digital technology in general, and finally, (5) support for families.

When we are left in the dark about the fate of a loved one, unable to forget or move on, the suffering never ends and hope turns to despair. Yet the families affected refuse to give up, no matter the cost, and they have blazed a trail for the humanitarians, scientists and jurists who have in recent years come up with the solutions presented in this issue of the Review. What makes them keep going,

31 ICRC, The Missing and Their Families: Summary of the Conclusions Arising from Events Held Prior to the International Conference of Governmental and Non-Governmental Experts (19-21 February 2003), Geneva, 2003, available at: www.icrc.org/eng/resources/documents/report/5jahr8.htm. See also ICRC, The Missing: ICRC Progress Report, Geneva, 2006, available at: www.icrc.org/eng/assets/files/other/icrc 002_0897.pdf.

32 See: www.icrc.org/en/publication/missing-migrants-and-their-families-icrcs-recommendations-policy-makers.

33 See: www.tracetheface.org.

34 See in particular, Olivier Dubois, Katharine Marshall and Siobhan Sparkes McNamara, "New Technologies and New Policies: The ICRC's Evolving Approach to Working with Separated Families", International Review of the Red Cross, Vol. 94, No. 888, 2012.

35 See “Q\&A: The ICRC's Engagement on the Missing and Their Families", in this issue of the Review. 
innovate and persevere? Estela Barnes de Carlotto closed the ICRC's 2017 "Gone but not Forgotten" conference in honor of the International Day of the Disappeared with these words:

We began our fight out of love. Love for a child, a grandchild, a husband or wife, a brother or sister. Our love is without end and without limits. We have carried out our struggle peacefully, without violence, hoping for occasions and opportunities to move forward under both the dictatorship and democracy. We are not full of hate or rancour. We have no desire for revenge. We want justice. And we are happy because clinging stubbornly to love has borne fruit. ${ }^{36}$ 